\section{Occupational asthma due to gas metal arc welding on mild steel}

\author{
O Vandenplas, F Dargent, J-J Auverdin, \\ J Boulanger, J-M Bossiroy, D Roosels, \\ $\mathrm{R}$ Vande Weyer
}

\begin{abstract}
Occupational asthma has been documented in electric arc welders exposed to manual metal arc welding on stainless steel. A subject is described who developed late and dual asthmatic reactions after occupational-type challenge exposure to gas metal arc welding on uncoated mild steel. (Thorax 1995;50:587-588)
\end{abstract}

Keywords: asthma, occupational diseases, bronchial provocation test, welding.

A number of electric arc welding techniques are used in industrialised countries. ${ }^{12}$ The most common process, manual metal arc welding, is performed with flux covered electrodes in order to protect melted metal from oxidation. Gas metal arc welding is an increasingly used technique in which an inert or active gas (argon, helium, or carbon dioxide) allows for the generation of an oxygen-free atmosphere.

Occupational asthma has been documented in workers exposed to manual metal arc welding on stainless steel. ${ }^{3}$ Asthma and systemic reactions have also been associated with welding metals coated with epoxy resins and chlorocontaining polymer lacquers. ${ }^{2}$ We describe a subject who developed asthmatic reactions when exposed to gas metal arc welding on uncoated mild steel.

\section{Case report}

A 21 year old man had been employed for three months as a welder in a workshop manufacturing automatic gates when he first experienced asthma. He welded pieces of uncoated mild steel using a gas metal arc welding process with a mixture of argon $(80 \%)$ and carbon dioxide $(20 \%)$ as the shielding gas. Before that time he had welded iron with a manual metal arc technique for one year without experiencing respiratory symptoms. Chest tightness, wheezing, and cough occurred at the end of the workshift on Mondays. The symptoms appeared earlier and worsened progressively throughout the week, and subsided after about one day off work. The subject never experienced myalgia, chills or fever. $\mathrm{He}$ was treated with inhaled beclomethasone $(1000 \mu \mathrm{g}$ daily) and fenoterol when necessary but this treatment failed to control the symptoms. He left his work four months after the onset of respiratory symptoms and was referred for in- vestigation eight months later. At that time he experienced asthma on exercise and did not take medication on a regular basis. $\mathrm{He}$ had smoked 10 cigarettes a day for six years and had no history of atopy. Skin prick tests with common inhalant allergens and sulphate salts of nickel, zinc, copper and manganese at $10 \mathrm{mg} /$ $\mathrm{ml}$ in saline gave negative results.

Serial monitoring of peak expiratory flow rates could not be performed because we were not allowed to send the subject back to his workplace. It was therefore decided to carry out occupational-type inhalation challenges in the hospital workshop. Baseline spirometric measurements showed a forced expiratory volume in one second $\left(\mathrm{FEV}_{1}\right)$ of $4 \cdot 221(100 \%$ predicted value) and $\mathrm{FEV}_{1} / \mathrm{FVC}$ of $66 \%(79 \%$ predicted). On the control day without exposure to occupational agents spontaneous fluctuations of $\mathrm{FEV}_{1}$ were less than $10 \%$. The provocative concentration of histamine causing a $20 \%$ fall in $\mathrm{FEV}_{1}\left(\mathrm{PC}_{20}\right)$ was $1.0 \mathrm{mg} / \mathrm{ml} .{ }^{4} \mathrm{Gas}$ metal arc welding on mild steel (electrode wire, Nertalic 70A, SAF, Alleur, Belgium) for two hours resulted in a late asthmatic response with a fall in $\mathrm{FEV}_{1}$ of $26 \%$ eight hours after exposure (figure). On the next morning bronchial responsiveness to histamine was not changed compared with the control day value $\left(\mathrm{PC}_{20}=\right.$ $0.9 \mathrm{mg} / \mathrm{ml}$ ). On the following day the subject was again exposed to gas metal arc welding on mild steel for two hours. He developed an immediate fall of $23 \%$ in $\mathrm{FEV}_{1}$ followed by progressive recovery and a late decrease reaching $25 \%$ at eight hours. On the next morning histamine $\mathrm{PC}_{20}$ remained unchanged $(1.1 \mathrm{mg} /$ $\mathrm{ml}$ ). One week later the subject welded mild steel using a manual metal arc process for two hours without developing significant changes in $\mathrm{FEV}_{1}$.

Two previously unexposed control asthmatic subjects (histamine $\mathrm{PC}_{20}$ values of 0.03 and $0.5 \mathrm{mg} / \mathrm{ml}$ ) exposed to gas metal arc welding on mild steel for two hours did not show significant changes in $\mathrm{FEV}_{1}$.

Environmental analysis during gas metal arc welding on mild steel was performed using

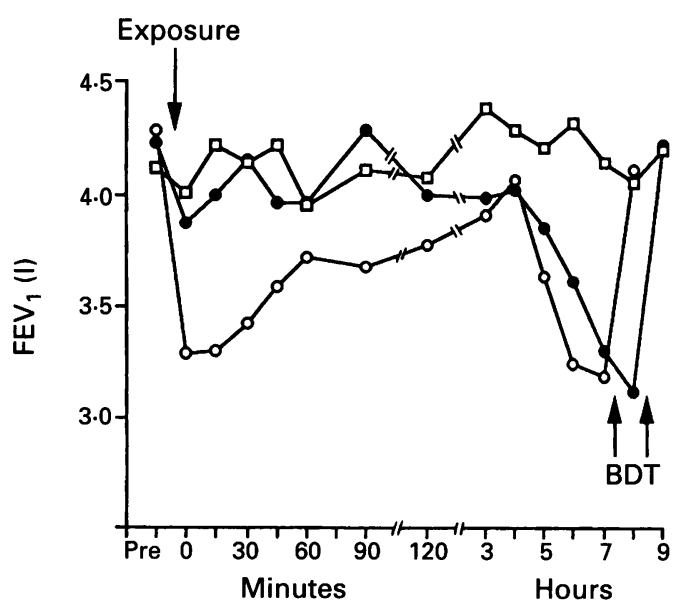

Changes in $F E V_{1}$ after welding for two hours on mild steel using a gas metal arc process during the first (O) and second (O) challenges as well as after manual metal arc welding (प). BDT=inhaled bronchodilator (salbutamol $200 \mu \mathrm{g})$. 
personal samplers located on the shoulders. The concentration of respirable particles was $2 \cdot 1 \mathrm{mg} / \mathrm{m}^{3}$. Flame atomic absorption spectrometry demonstrated concentrations of iron $\left(994 \mu \mathrm{g} / \mathrm{m}^{3}\right)$, manganese $\left(144 \mu \mathrm{g} / \mathrm{m}^{3}\right)$, and copper $\left(30 \mu \mathrm{g} / \mathrm{m}^{3}\right)$ to be below their respective threshold limit (TLV) values. Highly variable concentrations of ozone ranging from 0.06 to $0 \cdot 16 \mathrm{ppm}$ were measured using a TLD-1 tape monitor (MDA Scientific). Neither chromium, nickel, cobalt nor aldehydes were detected.

Specific inhalation challenge with ozone for two hours at a mean (SD) concentration of $0 \cdot 12(0.02) \mathrm{ppm}$ by the exposed subject did not cause significant changes in $\mathrm{FEV}_{1}$ nor in histamine $\mathrm{PC}_{20}(1 \cdot 2 \mathrm{mg} / \mathrm{ml})$.

\section{Discussion}

In our subject gas metal arc welding on mild steel elicited an isolated late asthmatic reaction and a dual reaction on repeated exposure. There is convincing evidence that these reactions were not due to a non-specific irritant effect. Late and dual reactions are more consistent with a hypersensitivity mechanism. Moreover, the change in the temporal pattern of the bronchial response from an isolated late reaction to a dual reaction on repeated challenge has also been documented with plicatic acid, a low molecular weight chemical responsible for asthma caused by red cedar wood dust. ${ }^{5}$ In our subject the asthmatic reactions were not associated with an increase in nonspecific bronchial hyperresponsiveness which can be observed, although inconstantly, after late reactions due to occupational agents. ${ }^{6} \mathrm{Gas}$ metal arc welding on mild steel did not induce a bronchial reaction in two control asthmatic subjects.

The agent(s) causing asthma in our subject could not be definitively identified. Welding fumes contain a complex mixture of metal oxide particulates originating from the evaporation of welded metals and consumable electrodes. ${ }^{12}$ Ultraviolet radiation in the arc can lead to the production of toxic gases, including oxides of nitrogen and ozone. In subjects with asthma due to manual metal arc welding on stainless steel Keskinen et $a \beta$ found that exposure to manual metal arc welding on mild steel as well as to gas metal arc welding on stainless steel did not induce asthmatic reactions. It was postulated, ${ }^{3}$ although unproved, that chromium and/or nickel were the causal agents since these metals are generated during stainless steel welding and have been documented as causing asthma in other occupations. ${ }^{7}$ In our subject the asthmatic reactions were specifically related to the gas metal arc welding procedure since manual metal arc welding on mild steel did not cause asthma. Using specific inhalation challenges we could reasonably exclude ozone as the causative agent.

To our knowledge this is the first report of asthmatic reactions caused by gas metal arc welding on uncoated low alloy steel. Awareness of this association may be important in view of the widespread use of this welding technique.

1 Sferlazza SJ, Beckett WS. The respiratory health of welders. Am Rev Respir Dis 1991;143:1134-48.

2 Sjögren B. Effects of gases and particles in welding and soldering. In: Zens $C$, Dickerson $O$, Horvath $E$, eds Occupational medicine. St Louis: Mosby-Year Book Inc, 1994:917-25.

3 Keskinen G, Kalliomaki PL Alanko K. Occupational asthma due to stainless steel welding fumes. Clin Allergy 1980;10 151-9.

4 Cockcroft DW, Killian DN, Mellon JJA, Hargreave FE. Bronchial reactivity to inhaled histamine: a method and clinical survey. Clin Allengy 1977;7:235-43.

5 Lam S, Tan F, Chan G, Chan-Yeung M. Relationship between types of asthmatic reaction, nonspecific bronchia reactivity, and specific IgE antibodies in patients with red cedar asthma. $\mathcal{f}$ Allergy Clin Immunol 1983;72:134-9.

6 Malo JL, Ghezzo H, L'Archevêque J, Cartier A. Late asthmatic reactions to occupational sensitizing agents: frequency of changes in nonspecific bronchial responsiveness quency of changes in nonspecific bronchial responsiveness and of response to inhaled $\beta_{2}$-adrenergic agent. F Allergy Clin Immunol 1990;85:834-42

7 Chan-Yeung M, Malo JL. Aetiological agents in occupational asthma. Eur Respir f 1994;7:346-71. 